\title{
Non-Compliance With Non-Study Device
}

National Cancer Institute

\section{Source}

National Cancer Institute. Non-Compliance With Non-Study Device. NCI Thesaurus. Code C139240.

An indication that a subject has not ag reed with, or followed the instructions related to, the non-study device. 